\title{
"CRIMEA PROJECT" OF A JEWISH AUTONOMY IN THE USA LIBERAL PUBLIC PERCEPTION (BASED ON THE NEW YORK TIMES MATERIALS)
}

\author{
Konstantin Yu. Mogarichev \\ Taurida Academy, V.I. Vernadsky Crimean Federal University, Simferopol, Russian Federation; \\ Museum of History of Simferopol, Simferopol, Russian Federation
}

\begin{abstract}
Introduction. "Crimea project" is unsuccessful attempts to create a Jewish national territorial autonomy on the territory of the Crimean Peninsula in 1920-1940s of the $20^{\text {th }}$ century. The topic was poorly elaborated in historiography. In this regard, this topic frequently became the ground for historical myths and pseudo-scientific statements. The main aim of this paper is to analyse the "Crimea project" coverage in American media in 1920-1940s of the $20^{\text {th }}$ century and to identify the patterns in topic presentations. Methods. In this paper, we used such methods as analysis, synthesis, retrospective analysis, the historical genetic method, historical comparative, and the analysis of text. We selected The New York Times newspaper as the main source as it is one of the oldest, continuous and credible media reflecting liberal agenda. Analysis. In the paper, we analyze articles devoted to "Crimea project" during $20-40$ s of the $20^{\text {th }}$ century. This article examines about 30 articles devoted to the Jewish agrarization, the project of creating a Jewish national autonomy in Crimea, the anti-Semitism problem in the USSR. This publications are examined in the context of struggle between zionists and anti-zionists in the USA as well. Results. Most articles focuse on the social aspect, namely agrarization. The political moments of "Crimea project" are addressed less frequently, mainly in the frame of the statements of Soviet officials on the possibility of creating a Jewish autonomy on the territory of the Steppe Ukraine and Northern Crimea. The paper pays attention to the authors' little knowledge on the real situation and mistakes in its coverage.
\end{abstract}

Key words: The New York Times, Crimea, Jews, Crimean ASSR, korenizatsiya, agrarization, press.

Citation. Mogarichev K.Yu. "Crimea Project" of a Jewish Autonomy in the USA Liberal Public Perception (Based on The New York Times Materials). Vestnik Volgogradskogo gosudarstvennogo universiteta. Seriya 4. Istoriya. Regionovedenie. Mezhdunarodnye otnosheniya [Science Journal of Volgograd State University. History. Area Studies. International Relations], 2019, vol. 24, no. 3, pp. 170-180. (in Russian). DOI: https://doi.org/10.15688/jvolsu4.2019.3.15

\section{«КРЫМСКИЙ ПРОЕКТ» ЕВРЕЙСКОЙ АВТОНОМИИ В ВОСПРИЯТИИ ЛИБЕРАЛЬНОЙ ОБЩЕСТВЕННОСТИ США (ПО МАТЕРИАЛАМ «ТНЕ NEW YОRК TIMES»)}

\author{
Константин Юрьевич Могаричев \\ Таврическая академия Крымского федерального университета им. В.И. Вернадского, \\ г. Симферополь, Российская Федерация; \\ Музей истории города Симферополя, г. Симферополь, Российская Федерация
} Аннотация. Введение. «Крымский проект»- это нереализованные попытки создания на территории
Крымского полуострова еврейской национально-территориальной автономии в 20-40-х гг. ХХ века. Данная
проблема практически не разработана в историографии. Часто, в силу своей слабой изученности, она явля- 
лась почвой для различных исторических мифов и псевдонаучных трактовок. Целями настоящей работы являются анализ освещения «Крымского проекта» в американских СМИ 20-40-х гг. ХХ в. и выявление закономерностей подачи материала различными авторами. Методы. В исследовании мы использовали методы анализа, синтеза, ретроспективного анализа, историко-генетический метод, историко-сравнительный, а также анализа текстового содержания. В качестве основного источника выбрана газета «The New York Times» как одно из старейших, непрерывно издаваемых и авторитетных изданий, отражающих либеральную повестку американской общественности. Анализ. В работе мы анализируем статьи, посвященные «Крымскому проекту» и опубликованные в «The New York Times» на протяжении 20-40-х гг. XX века. Всего исследуются более тридцати публикаций, которые посвящены еврейской сельскохозяйственной колонизации на юге СССР, планам создания еврейской автономии в Крыму, проблеме антисемитизма в СССР. Указанные публикации рассматриваются в контексте борьбы территориалистов и сионистов в американском еврейском обществе. Результаты. Большинство исследуемых материалов посвящены социальному аспекту, а именно процессу сельскохозяйственной колонизации. Политические моменты «Крымского проекта» затрагиваются реже, в основном в контексте резонансных заявлений советских высших должностных лиц о возможности создания еврейской автономии на территории степной Украины и северного Крыма. Обращает внимание недостаточная осведомленность авторов статей о реальном положении дел, и, соответственно, наличие ошибок в подаче материала.

Ключевые слова: «The New York Times», Крым, евреи, Крымская АCCP, коренизация, сельскохозяйственная колонизация, пресса.

Цитирование. Могаричев К. Ю. «Крымский проект» еврейской автономии в восприятии либеральной общественности США (по материалам «The New York Times») // Вестник Волгоградского государственного университета. Серия 4, История. Регионоведение. Международные отношения. -2019. - Т. 24, № 3. - С. 170 180. -DOI: https://doi.org/10.15688/jvolsu4.2019.3.15

Введение. «Крымский проект» - это нереализованные попытки создания на территории Крымского полуострова (в целом или его отдельной части) еврейской советской автономии в 20-40-х гг. XX века. Сложность изучения рассматриваемого вопроса заключается, с одной стороны, в том, что она представляет из себя «белое пятно» для современных историков. С другой стороны, в силу политизированности и традиционной остроты «еврейского вопроса» часто эта научная проблема становилась предметом конспирологических и откровенно ксенофобских мифов [3, с. 124].

По нашему мнению, в истории «Крымского проекта» отчетливо выделяются два этапа. Первый этап (первый «Крымский проект») датируется 20-30-ми гг. ХХ в. и связан с еврейской сельскохозяйственной колонизацией, проводившейся в Крыму, функционированием в Крыму структур Общества землеустройства евреев-трудящихся (ОЗЕТ) ${ }^{1}$, Комитета землеустройства евреев-трудящихся (КомЗЕТ) ${ }^{2}$, Агро-Джойнта ${ }^{3}$ и других благотворительных организаций. Он является отражением имевшей место тогда в СССР политики коренизации ${ }^{4}$. Второй этап (второй «Крымский проект») относится к 40-м гг. ХХ в. и является след- ствием деятельности Еврейского антифашистского комитета (ЕАК) и реакции на так называемое «Крымское письмо» ${ }^{5}$ [3, с. 127].

В настоящей работе мы предприняли попытку рассмотреть, как «Крымский проект» освещался и анализировался в американских средствах массовой информации (СМИ) того времени. Отметим, еврейская сельскохозяйственная колонизация в СССР во многом финансировалась американскими спонсорами еврейского происхождения. В качестве основного источника мы взяли статьи и заметки, помещенные в «The New York Times» старейшей, непрерывно издаваемой газете, отражающей либеральную повестку американской общественности. При этом данное издание, несомненно, пользовалось и пользуется сейчас весомым авторитетом и нередко влияло и влияет на отношение широкой американской общественности к тому или иному явлению жизни как внутри страны, так и на международной арене.

Методы и материалы. Проблема «Крымского проекта» остается малоисследованной. Достаточно сказать, что в историографии (как отечественной, так и зарубежной) ее активное изучение начинается только в конце 90 -х - начале 2000 годов. Заметим, что пуб- 
ликации, которые были бы посвящены исключительно «Крымскому проекту», практически отсутствуют. В основном исследователи рассматривают данную тему в контексте еврейской аграрной колонизации в Причерноморье в 20-30-х гг. XX в., межнациональных отношений в Крыму либо истории евреев СССР. В связи с тем, что историография вопроса подробно исследована нами в специальной статье [4, с. 85-98], ее детальное рассмотрение в рамках данной публикации представляется излишним.

В настоящей работе мы использовали методы анализа, синтеза, ретроспективного анализа, историко-генетический метод, историко-сравнительный, а также анализа текстового содержания.

Нами проанализированы все публикации в «The New York Times» (всего 23 материала) в период с 1924 по 1945 гг., посвященные в той или иной степени «Крымскому проекту». Применяя проблемный метод изложения, мы условно разделили исследуемые материалы по следующим вопросам: политическая составляющая «Крымского проекта»; еврейская сельскохозяйственная колонизация на юге СССР; борьба с антисемитизмом в СССР; конфликт сионистов и их оппонентов в контексте «Крымского проекта» и еврейской сельскохозяйственной колонизации.

Анализ. Политическая составляющая «Крымского проекта». Впервые обсуждение этой проблемы в «The New York Times» зафиксировано нами в статье от 18 февраля 1924 г. (фамилия автора отсутствует), в которой повествуется о так называемом «меморандуме Брагина» ${ }^{6}$, переданном газете Еврейским телеграфным агентством. «В России предложен новый план по решению “еврейской проблемы”. Основным компонентом плана, по данным автора, являлось создание советской еврейской автономной республики. Проект как таковой был презентован А. Брагиным, организатором сельскохозяйственной выставки в ноябре 1923 г., который предложил выделить территории северного Крыма и смежные районы Украины с причерноморскими городами ${ }^{7}$ для организации еврейской автономной республики. В качестве человеческой и трудовой базы новой национальной территориально-административной единицы предполагались еврейские крестьяне. Автор пишет, что идею уже поддержали Л. Троцкий, Л. Каменев и Г. Чичерин. Меморандум также был поддержан группой еврейских социальных работников, в том числе гражданских служащих советских учреждений. Еврейская секция (ВКП(б). $-K$. М.), традиционно оппозиционная к еврейскому движению (так указано в источнике), заняла нейтральную позицию. В заключении цитируются слова А. Брагина: «С развитием еврейской колонизации, в 1927 г. предполагается, что регион будет превращен в автономный самоуправляемый регион с еврейской администрацией» [21].

Однако в следующей публикации по данному вопросу от 13 июля 1924 г. отмечается, что первый секретарь «президента Калинина» (так обычно называли иностранные СМИ Председателя ЦИК СССР М.И. Калинина) М. Смидович ${ }^{8}$ в ответ на слухи о создании еврейской автономии заметил, что пока организация еврейской автономии невозможна, так как нет подходящей территории. По его мнению, советское правительство действительно собирается расселить 50000 евреев на 250 акрах земли южной Украины и Крыма. Как только это произойдет и реальный еврейский район будет создан, то появятся предпосылки к созданию республики. П.Г. Смидович также подчеркнул, что с увеличением государственного сектора и сворачиванием частного бизнеса положение евреев в городах ухудшилось и лучшим вариантом для них стало расселение на свободной земле. В силу скромных возможностей государство, конечно, будет им помогать. Однако основная финансовая нагрузка ляжет на ОРТ (Общество распространения труда. $-K . M$.) и другие иностранные еврейские организации [13].

В следующей публикации от 18 ноября 1926 г. Уолтер Дюранти, шеф Московского бюро Нью Йорк Таймс, в специальном репортаже пишет: «Советское правительство подтвердило свою полную поддержку еврейской колонизации». Автор подчеркивает, что «Советский президент» Михаил Калинин настаивает на национальном характере колонизации и говорит: «Еврейская территориальная единица должна быть создана в СССР, даже без помощи из-за за рубежа». По мнению М.И. Калинина, советская федеративная система 
предполагает, что каждый народ имеет свою родину и вместе все народы составляют братство. Однако без родины невозможно создание братских отношений. «Советский президент» видит евреев как автономную нацию в СССР и не желает их ассимиляции. При этом М.И. Калинин активно критикует сионизм, считая, что советские евреи «несколько тысячелетий жили здесь и имеют право получить здесь свое отечество». Поэтому советское правительство против эмиграции евреев в Палестину: именно в СССР они должны иметь свободное отечество со свободным трудом. Он также подверг критике антисемитов в партии и в государстве, а источником этого явления считает «враждебно-настроенные классы» и «черносотенную пропаганду» при царской власти. В этом же материале цитируется заявление Ю. Ларина ${ }^{9}$ о том, что еврейская республика со своим автономным правительством будет создана в северном Крыму и примыкающем к нему Приазовью. В заключении автор отдельно останавливается на проблеме антисемитизма, озвученной М.И. Калининым. В связи с этим он приводит выдержки из публикации В.В. Маяковского в газете «Известия», где в ответ на обвинения антисемитов в том, что советская власть излишне печется о евреях, выделяя им землю в Крыму, поэт напоминает о тяжелой доле этого народа во времена Царской России и Гражданской войны. Обрабатывая эту землю, евреи будут строить свое будущее и скоро «никто не сможет отличить еврея от русского в стране, где не будет наций и войн» [11].

После 1926 г. тема создания на территории Крыма еврейской автономии в «The New York Times» больше не освещалась. Однако в публикации корреспондента Уильяма Цукермана за 31 мая 1931 г. вскользь упоминаются еврейские автономные районы степной Украины и Крыма. Правда, автор показывает не очень хорошее владение материалом и, вероятно, пользовался устаревшей информацией. Например, он называет крымский Фрайдорф (совр. пгт. Новоселовское Раздольненского района Республики Крым) Найдорфом, указывая его в числе мест, где делопроизводство ведется на идише, тем самым формируя ядро будущей еврейской автономной республики, о цели которой заявил М.И. Калинин в 1926 году [30].
Еврейская сельскохозяйственная колонизация на юге СССР. Первое упоминание о еврейской сельскохозяйственной колонизации в Крыму на страницах «The New York Times» датируется 25 июля 1924 годом. В новостном сообщении отмечается, что поселения евреев-земледельцев на юге СССР будут основаны недалеко от уже существующих еврейских колоний, чья история восходит еще ко времени правления Екатерины II ${ }^{10}$, а также в районе Азово-Черноморского побережья, в том числе и северного Крыма. Далее сообщается, что советское правительство готово вести переговоры со всеми еврейскими организациями, которые могут помочь в достижении цели. В первую очередь требовались деньги и оборудование. Организациям-спонсорам будет позволено иметь своих представителей в колониях. Однако административное и политическое управление будет оставаться в руках власти СССР. В конце заметки подчеркивается, что «в еврейских кругах России и соседних странах идею встретили с некоторой долей скептицизма» [24].

В следующем сообщении по данной теме, датируемом 27 октября 1924 г. информируется, что правительство УССР уже начало перепись еврейского населения. Последняя необходима для оценки количества земли, требуемой для будущих колонистов. Считается, что государственных земель Украины должно хватить для обеспечения евреевземледельцев. При этом отдельно изучается вопрос о предоставлении части земли в Крыму, где мирные крымские татары могли бы стать идеальными соседями для будущих колонистов. Частично необходимые для организации переселения и обустройства людей затраты будут покрыты за счет средств американских частных фондов. В заключении подчеркивается, что большая часть евреев по всему миру, несмотря на скепсис сионистов, поддерживает усилия Правительства СССР, благодаря которым они (евреи. $-K . M$.) «наконец-то смогут почувствовать себя свободными, в безопасности и удовлетворенными жизнью» [14].

Отметим, что основная идея, рефреном проходящая тогда в заявлениях Джойнта «возращение на землю», то есть аграризация еврейского населения. Предполагалось, что 
это будет выходом из ситуации, в которой оказалась значительная часть еврейского населения СССР вследствие сегрегационной политики царской России, гражданской войны и признания бывших торговцев лишенцами. «Возвращение на землю» считалось единственным способом обеспечить евреев стабильным будущим. Это подчеркивал в своем интервью члену правления «Джойнта» Д. Брауну и П.Г. Смидович [23]. Напомним, что проект аграризации евреев СССР не был уникальным. Такие же попытки обустройства еврейского населения тогда были предприняты и в других регионах, например, в Латинской Америке [7].

Как заметил в свое время исследователь проблемы А. Кагедан, еще с середины XIX в. аграризация считалась в среде американского еврейства некой панацеей социально-политического развития народа, способной решить все проблемы, в том числе и антисемитизм [17, с. 163-164].

Тема колонизации фигурирует и в новостной ленте газеты. Так, 12 июля 1925 г. читатели информируются, что советское правительство готово выделить 10 миллионов долларов для финансирования еврейского землеустройства вдобавок к займам иностранных агентств [19].

12 июля 1928 г. секретарь Агро-Джойнта Й. Хайман выступил с опровержением слухов о том, что руководство СССР меняет свою политику в отношении евреев-колонистов, что расселение будет проводиться не компактно, а среди иноэтничного населения. Хайман также отрицает слухи о плохом урожае в колониях: в районе Херсона он действительно неудачен, но в районе Кривого Рога - вполне нормальный, а в Крыму - отличный [8].

17 февраля 1929 г. со ссылкой на Еврейское телеграфное агентство опубликована новость о конфликте между правительством Крымской АССР и центральным КомЗЕТом из-за якобы неэффективной работе КомЗЕТ в рамках колонизации в Крыму. Абзацем ниже информируется, что 8 февраля 1929 г. Агентство по колонизации в России (дочерняя организация Джойнта) подписало новый договор о колонизации без каких-либо изменений. От СССР его подписал М. Смидович (опять же, скорее всего имелся ввиду именно П.Г. Сми- дович), со стороны Джойнта - Й. Розен, Ф. Варбург, Д. Розенберг и Й. Хайман [22]. Ряд публикаций по рассматриваемой проблеме представляет из себя отчеты руководства Агро-Джойнта об инспекционных поездках в колонии.

30 мая 1925 г. Д. Браун, глава Объединенного еврейского фонда, известный своими антисионистскими взглядами, по возвращению в США пишет, что на момент его приезда уже 20000 еврейских поселенцев проживали в сельскохозяйственных колониях. У них имелись американское оборудование и кредиты на постройку домов. В качестве конечной цели он видит «возможность для евреев построить жизнь с нуля, на земле». По мнению Д. Брауна, если Джойнт соберет осенью 1927 г. 15 миллионов долларов, то к концу того же года появится возможность расселить до 100000 человек [6].

17 января 1926 г. сообщалось, что Ф. Варбург, президент Джойнта, вместе с директором Чикагского отделения А. Брекером вернулись в Берлин, побывав в 41 из 139 еврейских поселений на территории УССР и Крымской АССР. Ф. Варбург отметил успешность еврейской сельскохозяйственной колонизации там, отметив, что все идет в соответствии с планом: «Мы не можем уберечь первопроходца от тяжелых времен, когда он собирает свой первый осенний урожай и вынужден жить в халупе или землянке, но можем защитить его от ошибочных решений, обеспечим материалом. В результате получится первоклассный агроном. На второй год они уже имеют поля в хорошем состоянии, дома, покрытые крышей, окотившийся скот, построенные заборы. На третий год, после хорошего урожая, они уже в состоянии оплачивать долги кооперативному банку, достигнув стабильности. Еврейское фермерство полностью доказало свою жизнеспособность. Меньше чем за три года, благодаря тяжелому труду и новейшим методам и технологиям их поля оставляют позади "русских" соседей и могут сравниться с лучшими немецкими полями соседей в Крыму. ...Мы не могли бы достигнуть этого без Советского правительства, которое давало каждой семье по 350 рублей и освобождение от налогов, а также представляло бесплатную перевозку материалов и хорошую 
землю». Ф. Варбург видит в развитии еврейских колоний залог будущего мирного сосуществования с нееврейскими соседями [28]. Заметим, что заявления президента Джойнта перекликаются с сюжетом советского пропагандистского документального фильма «Евреи на земле» [5].

21 июля 1925 г. доктор Й. Розен, возвращаясь из трехлетнего путешествия по СССР, рассказывает о слабой, еще не полностью восстановившейся инфраструктуре, однако при этом упоминает о комфортабельных поездах. По его мнению, ключевой фактор успешного эксперимента с еврейскими сельскохозяйственными колониями - лояльное отношение Советского Союза, а также помощь государства в транспортировке и расселении людей [9].

В рамках рассматриваемой проблемы заслуживает упоминание от 15 июля 1928 г. о переселении «раскаявшихся» сионистов из Гдуд hа-Авода (גדוד העבודה, - в пер. с ивр. «рабочий батальон». $-K . M$.) в Крым, в специально подготовленное для них поселение в районе города Саки ${ }^{11}$. При этом подчеркивается, что в то же время власти СССР активно репрессируют «своих» сионистов. Известно, что лидеры последней легальной сионисткой организации Мишмар («Страж») арестованы, несколько десятков сионистов депортированы в Сибирь. Руководство колонией Мишмар (недалеко от г. Джанкой в северном Крыму. $-K . M$.$) и его имуществом передано Ком-$ 3ETy [27].

В статьях конца 20-х - начала 30-х гг. уже подчеркивается разочарование еврейского населения в крымской колонизации. Отмечается, что евреи из местечек СССР теряют интерес к переселению в колонии [16]. Причина - начало коллективизации и отказ восстановить в правах «лишенцев». Так, из 4610 подавших заявление на переезд на новое место жительства приехали только 1755. При этом ОЗЕТ отказывается направлять в села бывших торговцев [18].

В конце 20-х гг. XX в. журналисты «Тhe New York Times» параллельно с аграризацией начинают освещать и тему «индустриализации» евреев СССР. Материал за 30 мая 1925 г. отмечает, что Народный комиссариат национальностей и ВЦИК рекомендовали ОЗЕТу параллельно с развитием сельскохозяйственных колоний заняться также подготовкой кадров для развернувшийся в стране индустриализации [6].

Журналист У. Цукерман даже рассказал об успехах советских евреев на поприще индустриализации. Он заметил, что, в отличие от переселения на землю, в этой сфере иностранный капитал не требуется. По информации У. Цукермана, уже 30 тысяч евреев посещают рабочие курсы и в результате индустриализация вскоре может затмить колонизацию по своему влиянию на советских евреев. Он резюмирует статью заявлением: «Нация торговцев и ростовщиков становится нацией рабочих и крестьян» [30].

Борьба с антисемитизмом в СССР. Эта тема в контексте еврейской колонизации была популярна среди журналистов газеты [20; 25]. Например, 13 июля 1926 г. У. Дюранти изложил читателям тезисы М.И. Калинина (всего 15) о борьбе с антисемитизмом. Данные тезисы были подготовлены и опубликованы Михаилом Ивановичем в качестве ответа на письмо некоего коммуниста Овчинникова, в котором затрагивалась и тема еврейских сельскохозяйственных поселений на юге страны. Особое внимание к еврейскому населению М.И. Калинин объясняет ущемленностью их в правах в царской России, а также чудовищными погромами империалистической (Первой Мировой) и гражданской войн. При этом «всесоюзный староста» категорически отвергает фаворитизм в отношении евреев, заявляя, что богатые еврейские буржуа преследуются так же, как и буржуи других национальностей. Говоря о проекте создания еврейской автономии, М.И. Калинин, по У. Дюранти, заявил: «Пока евреи не составляют компактного большинства населения, говорить о создании автономии нельзя», «недостаток автономии мы скомпенсируем переселением евреев на землю». По его мнению, еврейские коммунисты считают, что предпочтительнее, чтобы евреи селились на юге СССР, чем в Палестине, и советское руководство разделяет это мнение. А то, что евреев переселяют в Крым, а русских - в Сибирь ${ }^{12}$, связано с климатической приспособленностью [10].

В связи с Крымской колонизацией в «Тhe New York Times» также стали появляться 
материалы, касающиеся будущего Биробиджана и создания там Еврейской автономной области.

Впервые эта тема затрагивается 19 июля 1928 года. «Советы собираются создать Великую советскую еврейскую республику в Сибири. В новой республике будут собственные законы. В Сибири, в Биробиджанском районе на реке Амур будет создано самое большое еврейское государство в мире. Оно будет известно как Еврейская ССР и будет иметь свой язык, законодательство и таможню и будет иметь огромную поддержку от Москвы. Несколько тысяч еврейских фермеров уже поехали осваивать сибирский район, который больше, чем Франция, и приблизительно равняется штату Техас. Будут созданы сельскохозяйственные, шахтерские и фабричные колонии. Район примыкает к китайской провинции Манчжурия, где проходит КВЖД. Манчжурия также переживает бум развития». Далее говорится: «Уже существуют независимые еврейские колонии в Крыму и Украине, но власти заявляют, что Биробиджан будет первым настоящим еврейским государством, независимым от Мандата или чужого влияния». Кроме того, со ссылкой на Еврейское телеграфное агентство сообщается, что из США на эти цели пришел 1 млн долларов. А к проблемам еврейских поселений Крыма и Украины вернутся после организации еврейской автономии в Биробиджане [26].

Наряду с восторженными отзывами, газета цитирует и критиков «Биробиджанского проекта»: «Ю. Ларин критикует Биробиджанский эксперимент, говорит, что он несостоятелен, в то же время он видит растущую перспективу северо-крымских колоний. Он заявляет, что Керчь может стать столицей нового еврейского района. В Биробиджане же нехватка хлеба из-за паводков». Там же можно прочитать «10 мая газета “Эмес" (в пер. с идиш «правда». $-K . M$.) писала, что советские финансовые комиссары активно вмешивались в жизнь еврейской кооперации и приводили их к упадку» [29].

Конфликт сионистов и их оппонентов в контексте «Крымского проекта» и еврейской сельскохозяйственной колонизации. Изданием, хоть и не очень активно, в контексте еврейской колонизации на юге СССР был озвучен конфликт между территориалистами (сторонниками создания еврейской государственности вне территории Палестины) и сионистами. Так, в статье от 12 января 1926 г. утверждается, что корреспонденты французской газеты «Le Matin» получили сведения от одного из членов городского совета Тель-Авива и городского подрядчика о том, что якобы президент Американо-Еврейского комитета Луи Маршалл договорился с Советским правительством о том, что новый еврейский национальный дом будет построен в Крыму. Последнее угрожает развитию еврейской Палестины. На это Луи Маршалл ответил, что «автор заявления является кандидатом в психиатрическую больницу». По его заявлению, у Джойнта нет политической цели и что единственной задачей этой организации является «возвращение на землю» еврейского населения Восточной Европы, ибо это является гарантией выживания евреев в нынешних условиях [12].

Следующий материал от 14 сентября 1925 г. имеет пометку «специально для издания». В нем говорится, что в отеле Бенджамина Франклина на конференции собрались представители еврейской общественности и отчитались о сборе 1 млн долларов на помощь евреям Европы. Известный американский предприниматель еврейского происхождения Дж. Розенвальд заявил, что его взнос был частью 3,9 миллионного сбора, который будет в течении трех лет собран для осуществления проекта «Возврата к земле», главной целью которого станет облегчение участи «лишенцев» и пострадавших от экономической политики СССР. Однако не все участники съезда позитивно отнеслись к отправке такой суммы средств на еврейскую колонизацию в СССР. В частности, некто доктор Шерман высказывал опасения, что нельзя вкладывать такие огромные деньги в страну, с которой даже нет дипломатических отношений, тем более с большевистским строем. Он напомнил, что СССР сам богат ресурсами. Сионисты настаивали, что подобный подход отвлекает от репатриации в Палестину, что исторический опыт проживания евреев на территории Российской империи не очень позитивен и что советское правительство не стабильное. В ответ сторонники колонизации в СССР, в том 
числе Й. Розен, отчитались о начале работ и поделились планами на будущее. В конце дня было выпущено компромиссное заявление о том, что конгресс поддерживает как колонизацию в СССР, так и в Палестине [15].

В другом материале утверждается, что на сионисткой конференции 1924 г. в отеле Пенсильвания, делегаты осудили попытки расселения евреев в Крыму и Мексике, потому что там они будут зависеть от капризов местных правительств [19].

В заключении данного раздела заметим: мы просмотрели подборку «The New York Times» за 1944-1945 гг. в надежде найти какие-либо упоминания о втором «Крымском проекте». Однако такие материалы нам выявить не удалось. Это подтверждает выводы российского исследователя Г. Костырченко о том, что обсуждение второго «Крымского проекта» не выходило за пределы кабинетных переговоров [2, с. 456-457].

Результаты. Рассмотрев публикации газеты «The New York Times», посвященные еврейской сельскохозяйственной колонизации на юге СССР и проекту создания в Крыму Еврейской советской республики, мы пришли к следующим выводам:

1. Освещение данной темы в издании следует признать фрагментарным, без наличия единой системы подачи материала.

2. Большинство статей и заметок посвящены сельскохозяйственному аспекту колонизации.

3. Политическая составляющая «Крымского проекта» затрагивалась в основном в связи с резонансными заявлениями политиков, такими как «Меморандум Брагина» 1924 г. или «Декларация Калинина» 1926 года.

4. Журналисты доносили до читателя идею о том, что переселение евреев на землю сможет решить проблему «лишенцев», дать людям надежную социальную базу, спасти их от голода, защитить от антисемитизма. Отмечалось, что подобная точка зрения характерна как для властей СССР, так и для «американской» стороны.

5. Во многих материалах присутствуют фактические ошибки и неточности, что свидетельствует о недостаточной осведомленности журналистов о реалиях.

6. Практически отсутствуют «репортажи с мест», в основном все материалы - это изло- жение новостей Еврейского телеграфного агентства и пересказы статей из советских газет.

7. Отмечается определенная симпатия авторов к еврейской колонизации в Крыму. Это не случайно. Например, У. Дюранти известен своей просоветской позицией по многим вопросам, а У. Цукерман был последовательным противником сионизма и поддерживал альтернативные сионистскому проекты.

8. В газете обойдены вниманием имевшие место конфликты поселенцев с местным населением и ОЗЕТа - с руководством Крымской АССР в 1924-1928 годах.

9. С начала $30-x$ гг. тема еврейской колонизации в Крыму уступает освещению создания еврейской автономии в Биробиджане. Причем, если Крымская колонизация упоминалась больше в контексте аграрном, то Биробиджанская изначально рассматривалась в качестве создания некоего еврейского государства.

В целом можно заключить, что, судя по рассмотренному материалу, равно как и по данным других источников, предложения о создании национально-территориальной еврейской автономии в Крыму и на Южной Украине исходили от советских представителей. Американские еврейские организации больше интересовались возможностью организации еврейских аграрных поселений. Отметим настороженность и неприятие сионистски настроенных организаций к идее развития в СССР еврейской сельскохозяйственной колонизации, и, соответственно, организации еврейской автономии.

\section{ПРИМЕЧАНИЯ}

${ }^{1}$ ОЗЕТ, или Всесоюзное общество по земельному устройству трудящихся евреев в СССР,организация, созданная в 1924 г. и ставившая целью привлечение советских евреев к земледельческому труду.

${ }^{2}$ КомЗЕТ, или Комитет по земельному устройству еврейских трудящихся при президиуме Совета национальностей Центрального исполнительного комитета (ЦИК) СССР, - организация, созданная 29 августа 1924 г. по постановлению ЦИК СССР с целью так называемой продуктивизации еврейского населения, привлечения его к производительному, в первую очередь земледельческому, труду.

3 Агро-Джойнт - дочерняя корпорация Американского еврейского распределительного коми- 
тета (Джойнта), созданная в 1924 г. и непосредственно занимавшаяся финансированием еврейской аграрной колонизации в СССР в 1924-1937 годах.

${ }^{4}$ Коренизация - культурная и административная политика в СССР 20-х - первой половины 30-х гг. XX в., которая заключалась в развитии национальных языков и увеличении количества национальных кадров в партийных и советских органах.

5 «Крымское письмо» - письмо руководства Еврейского антифашистского комитета властям СССР с предложением о создании еврейской республики на территории Крыма в 1944 году.

${ }^{6}$ А. Брагин - советский общественный деятель и публицист 20-30 гг. ХХ в., член президиума ОЗЕТ, один из идеологов еврейской сельскохозяйственной колонизации и «Крымского проекта». «Меморандумом Брагина» было названо заявление о планах создания еврейской автономной республики на территории севера Крымской АССР и юга УССР.

${ }^{7}$ Скорее всего, речь идет о Николаеве, Одессе и Херсоне.

8 Здесь явная ошибка автора публикации. Несомненно, имеется в виду Петр Гермогенович Смидович, видный в то время партийный и государственный деятель, первый председатель КомЗЕТа.

9 Ю. Ларин - российский революционер, известный экономист, председатель ОЗЕТ. Один из идеологов «крымского проекта».

${ }^{10}$ Несомненно, журналисты ошиблись, так как первые еврейские поселения на юге Украины относятся к началу XIX в., то есть ко времени правления Александра I.

11 Имеется ввиду поселение Войо-Ново, совр. с. Листовое Сакского района.

12 Такая трактовка была популярна среди антисемитски настроенных советских граждан (см., например: [1, с. 165-168]).

\section{СПИСОК ЛИТЕРАТУРЫ}

1. Измозик, В. «Еврейский вопрос» в частной переписке советских граждан середины 1920-х гг: по материалам перлюстрации / В. Измозик // Вестник Еврейского университета в Москве. - М. : Иерусалим, 1994. - № 3 (7). - С. 164-188.

2. Костырченко, Г. В. Тайная политика Сталина. Власть и антисемитизм / Г. В. Костырченко. М. : Международные отношения, 2001. - 784 с.

3. Могаричев, К. Ю. Два этапа «Крымского проекта»: к постановке проблемы / К. Ю. Могаричев // Крымский гуманитарный вестник : сб. науч. ст. / отв. ред. А. Н. Рудяков. - Симферополь : ИП Минакир И. Л., 2018. - С. 123-127.

4. Могаричев, К. Ю. К вопросу о проектах еврейской автономии в Крыму в 1920-1940 гг.: истори- ографический аспект / К. Ю. Могаричев // Ученые записки Крымского Федерального университета имени В.И. Вернадского. Серия «Исторические науки». - 2018. - Т. 4 (70), № 2. - С. 85-98.

5. Роом, А. Евреи на земле / А. Роом. - Электрон. текстовые дан. - Режим доступа: https://www. youtube.com/watch?v=vLzmeG84YYc (дата обращения: 07.09.2018). - Загл. с экрана.

6. Browns, D. A. Tells on Our Aid in Crimea /D. A. Browns // The New York Times. - 1925. - May30.

7. Dekel-Chen, J. Jewels from the Earth (2017) / J. Dekel-Chen // Concordia University. - Electronic text data. - Mode of access: https://www.youtube. $\mathrm{com} /$ watch $\mathrm{v}=\mathrm{f} 4 \mathrm{mClRHP} 288 \& \mathrm{t}=2967 \mathrm{~s}$ (date of access: 07.09.2018). - Title from screen.

8. Denies New Soviet Policy // The New York Times. - 1928. - July 12.

9. Dr. Rosen Found Russia Improved // The New York Times. - 1925. - July 21.

10. Duranty, W. Kalenin Defends Jews in Crimea /W. Duranty // The New York Times. - 1926. - July 13.

11. Duranty, W. Soviet to Give Jews National Autonomy / W. Duranty // The New York Times. 1926. - Nov. 18.

12. False Rumor in Palestine // The New York Times. - 1926. - Jan. 12.

13. First colonization, then - autonomy // The New York Times. - 1924. - July 13.

14. Free Land for Jews Planned in Russia // The New York Times. - 1924. - Oct. 27.

15. Gives $\$ 1000000$ for Jewish Relief// The New York Times. - 1925. - Sept. 14.

16. Jews Avoid Colonies // The New York Times. 1930. -Apr. 6.

17. Kagedan, A. L. America Jews and the Soviet Experiment: Agro-Joint Project, 1924-1937/A. L. Kagedan // Jewish Social Studies. - 1981. - Vol. 43, № 2. P. 153-164.

18. National Minorities Concil Calls for Quick Land Settlement// The New York Times. - 1929. - Feb. 3 .

19. Opposed to Jews Settling in Mexico // The New York Times. - 1924. - Sept. 8.

20. See Antisemitism Reviving in Russia // The New York Times. - 1926. - Oct. 17.

21. Soviet Chiefs Favor Russian Jewish State // The New York Times. - 1924. - Feb. 18.

22. Soviet Colonization in Crimea Criticisied // The New York Times. - 1929. - Feb. 17.

23. Soviet Helps Jews to Get Back to the Land // The New York Times. - 1925. - July 12.

24. Soviet Offer Jews Land//The New York Times. 1924. - July 25.

25. Soviet Still Wars on Antisemitism // The New York Times. - 1929. - May 19.

26. Soviet to Create Great Jewish State in Siberia // The New York Times. - 1928. - July 19. 
27. Soviet Wars on Zionism // The New York Times. - 1928. - July 15.

28. Varburg Reports Colonies Thriving // The New York Times. - 1926. - Jan.12.

29. Zuckerman, W. The Biro-Bidjan Project in Eastern Siberia Stirs Opposition as a Possible Rival to Palestine / W. Zuckerman // The New York Times. 1934. - Aug. 26

30. Zukerman, W. Status of the Jews in Russia is Transformed by Revolution / W. Zuckerman // The New York Times. - 1931. - May 31.

\section{REFERENCES}

1. Izmozik V. «Evreyskiy vopros» v chastnoy perepiske sovetskikh grazhdan serediny 1920-kh gg.: po materialam perlyustratsii ["The Jewish Question" in Private Life of Soviet Citizens in the Middle of 1920-s: on Materials of Post Interception]. Vestnik Evreyskogo universiteta $v$ Moskve [Publisher of Jewish University in Moscow]. Moscow, Jerusalem, 1994, no. 3 (7), pp. 164-188.

2. Kostyrchenko G.V. Taynaya politika Stalina. Vlast $i$ antisemitizm [Secret Policy of Stalin: Power and Anti-Semitism]. Moscow, Mezhdunarodnye otnosheniya Publ., 2001. 784 p.

3. Mogarichev K.Yu. Dva etapa «Krymskogo proekta»: k postanovke problemy [Two Stages of the Crimea Project: On Problem Statement]. Rudyakov A.N., ed. Krymskiy gumanitarnyy vestnik: sb. nauch. st. Simferopol, IP Minakir I.L., 2018, pp. 123-127.

4. Mogarichev K.Yu. K voprosu o proektakh evreyskoy avtonomii v Krymu v 1920-1940 gg: istoriograficheskiy aspekt [On Projects of the Jewish Autonomy in Crimea 1920-1940: Historiographical Aprroach]. Uchenye zapiski Krymskogo Federalnogo universiteta imeni V.I. Vernadskogo. Istoricheskie nauki [Scientific Notes of V.I. Vernadsky Crimean Federal University. Historical Science], 2018, vol. 4 (70), no. 2, pp. 85-98

5. Room A. Evrei na zemle [The Jews on Land]. URL: https://www.youtube.com/watch? $\mathrm{v}=\mathrm{vLzmeG}$ 84YYc (accessed 7 September 2018).

6. Browns D.A. Tells on Our Aid in Crimea. The New York Times, 1925, May 30.

7. Dekel-Chen J. Jewels from the Earth (2017). URL: https://www.youtube.com/watch? $\mathrm{v}=\mathrm{f} 4 \mathrm{mClRHP}$ $288 \& \mathrm{t}=2967 \mathrm{~s}$ (accessed 7 September 2018).
8. Denies New Soviet Policy. The New York Times, 1928, July 12.

9. Dr. Rosen Found Russia Improved. The New York Times, 1925, July 21.

10. Duranty W. Kalenin Defends Jews in Crimea. The New York Times, 1926, July 13.

11. Duranty W. Soviet to Give Jews National Autonomy. The New York Times, 1926, November 18.

12. False Rumor in Palestine. The New York Times, 1926, January 12.

13. First Colonization, Then - Autonomy. The New York Times, 1924, July 13.

14. Free Land for Jews Planned in Russia. The New York Times, 1924, October 27.

15. Gives $\$ 1000000$ for Jewish Relief. The New York Times, 1925, September 14.

16. Jews Avoid Colonies. The New York Times, 1930, April 6.

17. Kagedan A.L. America Jews and the Soviet Experiment: Agro-Joint Project, 1924-1937. Jewish Social Studies, 1981, vol. 43, no. 2, pp. 153-164.

18. National Minorities Concil Calls for Quick Land Settlement. The New York Times, 1929, February 3.

19. Opposed to Jews Settling in Mexico. The New York Times, 1924, September 8.

20. See Antisemitism Reviving in Russia. The New York Times, 1926, October 17.

21. Soviet Chiefs Favor Russian Jewish State. The New York Times, 1924, February 18

22. Soviet Colonization in Crimea Criticisied. The New York Times, 1929, February 17.

23. Soviet Helps Jews to Get Back to the Land. The New York Times, 1925, July 12.

24. Soviet Offer Jews Land. The New York Times, 1924, July 25.

25. Soviet Still Wars on Antisemitism. The New York Times, 1929, May 19.

26. Soviet to Create Great Jewish State in Siberia. The New York Times, 1928, July 19.

27. Soviet Wars on Zionism. The New York Times, 1928, July 15.

28. Varburg Reports Colonies Thriving. The New York Times, 1926, January 12.

29. Zuckerman W. The Biro-Bidjan Project in Eastern Siberia Stirs Opposition as a Possible Rival to Palestine. The New York Times, 1934, August 26.

30. Zukerman W. Status of the Jews in Russia is Transformed by Revolution. The New York Times, 1931, May 31. 


\section{ПОЛИТИЧЕСКИЕ НАУКИ И РЕГИОНОВЕДЕНИЕ}

\section{Information about the Author}

Konstantin Yu. Mogarichev, Postgraduate Student, Department of Modern and Contemporary History, Taurida Academy, V.I. Vernadsky Crimean Federal University, Yaltinskaya St., 20, 295007 Simferopol, Russian Federation; Researcher, Museum of History of Simferopol, Pushkina St., 17, 295000 Simferopol, Russian Federation, kostiamohar@outlook.com, https://orcid.org/0000-0002-2206-5871

\section{Информация об авторе}

Константин Юрьевич Могаричев, аспирант кафедры новой и новейшей истории, Таврическая академия Крымского федерального университета им. В.И. Вернадского, ул. Ялтинская, 20, 295007 г. Симферополь, Российская Федерация; научный сотрудник, Музей истории города Симферополя, ул. Пушкина, 17, 295000 г. Симферополь, Российская Федерация, kostiamohar@outlook.com, https://orcid.org/0000-0002-2206-5871 